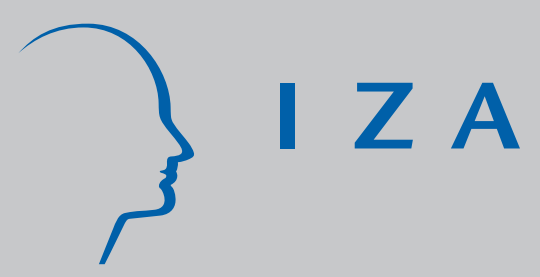

IZA DP No. 539

Labour-Market Institutions and Macroeconomic Shocks

Yu-Fu Chen

Dennis Snower

J uly 2002 


\title{
Labour-Market Institutions and Macroeconomic Shocks
}

\author{
Yu-Fu Chen \\ University of Dundee \\ Dennis Snower \\ Birkbeck College, University of London, \\ CEPR and IZA Bonn \\ Gylfi Zoega \\ Birkbeck College, University of London
}

\author{
Discussion Paper No. 539 \\ July 2002
}

IZA

P.O. Box 7240

D-53072 Bonn

Germany

Tel.: +49-228-3894-0

Fax: +49-228-3894-210

Email: iza@iza.org

This Discussion Paper is issued within the framework of IZA's research area Welfare State and Labor Market. Any opinions expressed here are those of the author(s) and not those of the institute. Research disseminated by IZA may include views on policy, but the institute itself takes no institutional policy positions.

The Institute for the Study of Labor (IZA) in Bonn is a local and virtual international research center and a place of communication between science, politics and business. IZA is an independent, nonprofit limited liability company (Gesellschaft mit beschränkter Haftung) supported by the Deutsche Post AG. The center is associated with the University of Bonn and offers a stimulating research environment through its research networks, research support, and visitors and doctoral programs. IZA engages in (i) original and internationally competitive research in all fields of labor economics, (ii) development of policy concepts, and (iii) dissemination of research results and concepts to the interested public. The current research program deals with (1) mobility and flexibility of labor, (2) internationalization of labor markets, (3) welfare state and labor market, (4) labor markets in transition countries, (5) the future of labor, (6) evaluation of labor market policies and projects and (7) general labor economics.

IZA Discussion Papers often represent preliminary work and are circulated to encourage discussion. Citation of such a paper should account for its provisional character. A revised version may be available on the IZA website (www.iza.org) or directly from the author. 
IZA Discussion Paper No. 539

July 2002

\begin{abstract}

\section{Labour-Market Institutions and Macroeconomic Shocks*}

Macroeconomic shocks and labour-market institutions jointly determine employment growth and economic performance. The effect of shocks depends on the nature of these institutions and the effect of institutional change depends on the macroeconomic environment. It follows that a given set of institutions may be appropriate at certain times in some countries while not appropriate elsewhere. We derive a dynamic model of labour demand in which the effect of firing costs on labour demand depends on the macroeconomic environment: When the level of macroeconomic activity is expected to drop and/or the trend rate of productivity growth is small, a rise in firing costs affects mainly (and adversely) the hiring decision and not the firing decision. This makes firing costs harmful when they may appear to be most appropriate. The intuition behind these results is quite straightforward: When managers fear that demand may fall in the future they value the right to fire workers. It follows that by making this option more costly, firing costs reduce the value of workers with adverse consequences for hiring and firing.
\end{abstract}

JEL Classification: E32, J23, J24, J54

Keywords: $\quad$ firing costs, stochastic demand, hiring and firing, real options

Gylfi Zoega

Department of Economics

Birkbeck College

University of London

7-15 Gresse Street

London W1P 2LL

UK

Tel.: +44 (171) 6316416

Email: gzoega@econ.bbk.ac.uk

${ }^{*}$ We thank Juan Dolado and Margaret Stevens for comments. 
Labour-market rigidities are often blamed for the European unemployment problem in what is commonly termed "Eurosclerosis" ". Recent studies by the OECD link reforms to reduce labour-market rigidies ${ }^{2}$ to reductions in unemployment (e.g. Elmeskov, Martin and Scarpetta (1998) and OECD (2000)). This line of argument - according to which rigidities such as firing costs discourage firms from employment - has become increasingly persuasive over the past two decades, as the EU unemployment rate has risen steadily relative to the US rate. However, it then becomes a mystery why the EU unemployment rate was about half the US rate throughout much of the 1950s and 1960s, even though job-security legislation ${ }^{3}$ and other impediments to hiring and firing have been more stringent in Europe throughout most of the postwar period. It appears that there is no simple inverse relation between labour-market rigidities and unemployment. Instead, it seems that these rigidities might promote employment in some circumstances and reduce it in others.

A partial rationale for this possibility is provided by recent work by Phelps (1994), Blanchard and Wolfers (2000), Fitoussi, Jestaz, Phelps and Zoega (2000) and Phelps and Zoega (2001) who show empirically how unemployment benefits, the duration of these benefits, the density and coverage of labour unions, and employment-protection legislation which takes the form of fixed costs of firing - jointly determine the employment effects of macroeconomic shocks. Prominent among these shocks are changes in the rate of productivity growth (Pissarides, 1990; Hoon and Phelps, 1997), changes in real oil prices (Carruth, Hooker and Oswald, 1998), and changes in world real interest rates (Phelps, 1994). A recent paper by Ljungqvist and Sargent (1998) shows how an increase in economic turbulance - arising from the restructuring from manufacturing to service industries and the adoption of new technologies - in conjunction with high unemployment benefits can contribute to persistently high unemployment. Diaz and Snower (1996) demonstrate how the

\footnotetext{
${ }^{1}$ See Giersch (1985).

${ }^{2}$ The actual rules and regulations that affect the relationship between employers and employees in the OECD concern administrative authorizations, minimum-notice periods, severence pay, unfair dismissals and restrictions on layoffs for economic reasons. In our analysis, we will summarise this employmentprotection legislation with one summary index of firing costs.

${ }^{3}$ One rationale for these restrictions is that they internalise the social costs of dismissing a worker hence the cost of reallocating him to a new sector - and therefore cause firms to take these external considerations into account when deciding on a dismissal (Lindbeck and Snower (1988), Booth and Zoega (1994)). There is the added benefit that to the extent that average tenure becomes longer, both workers and firms may be more willing to invest in general - as well as firm-specific - skills.
} 
employment effects of employment-adjustment costs depend on the persistence of macroeconomic shocks.

In this paper, we describe how the effects of firing costs on hiring and firing depend on macroeconomic factors. We show how the rate of productivity growth and the likelihood of large-scale recessions (i.e. the probability of adverse demand shocks) determines the effect of firing costs. In particular, firing costs may have no deleterious employment effects - and might even stimulate employment - if productivity grows sufficiently fast and the possibility of major recessions is small. These are conditions that, on the whole, prevailed in the 1950s and 1960s. Subsequently, however, in the 1970s and 1980s, productivity growth slowed down and the likelihood of major recessions rose (particularly in conjunction with oil price and other raw material price shocks). We show that under these adverse conditions, firing costs can have a severely contractionary effect on employment, leading to high unemployment.

Our analysis differs from that of Bertola (1990) in that he shows that in the presence of firing costs firms tend to demand less labour in good times and more labour in bad times with the result that employment is more stable where employment protection is more stringent. In contrast, we describe how medium-term macroeconomic factors - i.e. the trend rate of growth of labour productivity and the possibility of adverse demand shocks determine the effectiveness of firing costs which implies that firing costs may raise or lower average employment depending on the macroeconomic environment.

Bertola (1990) and Bentolila and Bertola (1990) demonstrate how the asymmetry of adjustment costs - that is hiring- and firing costs - the rate of time discounting and the expected rate of attrition affect the long-run bias in firms' employment policies. We do not dispute their theoretical insights but we show explicitly how the effectiveness of firing costs depends in addition on the stochastic, macroeconomic environment in which firms operate. Thus raising firing costs may raise average employment in one country while reducing it in others. Moreover, Bertola (1990) finds no empirical support for an adverse effect of firing costs on average employment. We find that once the interactions between firing costs and the macroeconomic environment are taken into account, we can detect a significant relationship - positive or negative depending on the circumstances - between firing costs and average unemployment in a pooled sample of OECD countries. 
In Section I we derive a theoretical model of hiring and firing when labour is a quasi-fixed asset (see Oi, 1962) and there are linear, asymmetric costs of hiring and firing. In Section II we show how a change in the macroeconomic environment from high productivity growth and positive expected demand shocks to low growth and negative expected demand shocks will make firing costs harmful to employment. Finally, in Section III, we take a look at data on unemployment and labour-market institutions for nineteen OECD countries and conclude that the predictions of our model are consonant with the data.

\section{Model}

We consider the behaviour of a representative firm which finds itself facing stochastic demand for its output and linear costs of hiring and firing workers. We model the firm's hiring and firing decisions by deriving the two thresholds at which hiring and firing become optimal. ${ }^{4}$ Both of these decisions may be interpreted as intertemporal investment decisions.

The firm has a linear production technology (1) and faces a linear output demand function (2)

$$
\begin{gathered}
Q=g N, \\
P=Z-b Q,
\end{gathered}
$$

where $Q$ denotes production and sales, $N$ is the size of the firm's workforce, $g$ is labour productivity, $P$ is the product price, and $Z$ is an additive demand parameter. The number of employees quitting is

$$
d N=-\delta N d t
$$

where $\delta$ is the quit rate. Labour productivity grows at the exponential rate $\eta_{g}$

$$
d g=\eta_{g} g d t
$$

and the demand parameter $Z$ follows a combined geometric Brownian motion and jump process;

$$
d Z=\eta_{Z} Z d t+\sigma_{Z} Z d \Phi-Z d q_{1}+Z d q_{2}
$$

where $\Phi$ is a Wiener process; $d z=\varepsilon \sqrt{d t}$ (since $\varepsilon$ is a normally distributed random variable with mean zero and a standard deviation of unity), $\eta_{Z}$ is the drift parameter and

\footnotetext{
${ }^{4}$ For simplicity, we ignore inventories and the possibility of temporary layoffs.
} 
$\sigma_{Z}$ the variance parameter, $d q_{1}$ and $d q_{2}$ are the increments of Poisson processes (with mean arrival rates $\lambda_{1}$ and $\lambda_{2}$ ), and $d q_{1}, d q_{2}$ and $d \bar{\sigma}$ are independent to each other (so that $\mathrm{E}\left(\mathrm{d} \omega \mathrm{d} q_{1}\right)=0, \mathrm{E}\left(\mathrm{d} \omega \mathrm{d} q_{2}\right)=0$, and $\left.\mathrm{E}\left(\mathrm{d} q_{1} \mathrm{~d} q_{2}\right)=0\right)$. It is assumed that if an "event 1 " (or "event 2") occurs, $q_{1}$ (or $q_{2}$ ) falls (or increases) by some fixed percentage $\phi_{1}$ (or $\phi_{2}$ ) with probability 1 . Thus equation (5) implies that product demand will behave as a geometric Brownian motion, but over each time interval $d t$ there is a small probability $\lambda_{1} d t$ (or $\lambda_{2} d t$ ) that it will drop (or rise) to $1-\phi_{1}$ (or $1+\phi_{2}$ ) times its original value, and it will then continue fluctuating until another event occurs.

We model expectations about the future through the parameters $\sigma_{\mathrm{Z}}, \lambda_{1}, \lambda_{2}, \phi_{1}, \phi_{2}$ and $\eta_{Z}$. When $\sigma_{Z}$ is large, there is much uncertainty about the future. When $\lambda_{1}\left(\right.$ or $\left.\lambda_{2}\right)$ is positive and large, we expect large discrete negative (positive) shocks. We are interested in testing the implications of different parameter configurations for the effect of firing costs on average employment.

Combining (1) and (2) gives

$$
P \cdot Q=g Z N-b g^{2} N^{2} .
$$

The revenue function is concave in labour productivity and employment.

The firm faces a very small hiring cost $T$ per new employee and a much larger firing cost $F$ per dismissed worker. If the worker quits, the firm bears no firing cost. We view $F$ as a summary indicator of the strictness of employment-protection legislation. However, we must note that such restrictions have multiple dimensions that are not captured in our simple framework. $^{5}$

The real wage $w$ is assumed to grow at the same rate as productivity $\eta_{g}$. In contrast, we assume that discrete jumps in demand are not reflected in the wage. This assumes the existence of real-wage rigidity which makes labour-demand shocks affect employment and not real wages. Importantly, we do not model the effects of firing costs on wages. Our model describes the effects of firing costs on job creation and destruction taking real wages as given. ${ }^{6,7}$

\footnotetext{
${ }^{5}$ See footnote 2 .

${ }^{6}$ In this we are supported by the empirical results of Bertola (1990) who shows - using a cross section of ten OECD countries - that firing costs did not prevent wages from adjusting following the oil-price shocks of the 1970s. In contrast, Blanchard and Portugal (1998) show that countries with higher firing
} 
Using Itô's Lemma, the Bellman equation for the value $V(Z, g, N)$ of the firm's stock of workers at time zero, in the continuation region is

$$
\begin{aligned}
& \rho V=\left(g Z N-b g^{2} N^{2}\right)-w N-\delta N V_{N}+\eta_{g} g V_{g} \\
& \quad+\eta_{Z} Z V_{Z}+\frac{1}{2} \sigma_{Z}^{2} Z^{2} V_{Z Z}-\lambda_{1}\left\{V-V\left[\left(1-\phi_{1}\right) Z\right]\right\}+\lambda_{2}\left\{V\left[\left(1+\phi_{2}\right) Z\right]-V\right\},
\end{aligned}
$$

where the value of future hires or fires is not taken into account and $\rho$ is the real rate of interest. The first term on the right-hand side is revenue - defined by equation (6) $-w N$ is the wage bill, $\delta N V_{N}$ is the loss due to quits, $\eta_{g} g V_{g}$ is the gain due to productivity growth, and the last three terms are the change in the value of the firm caused by changes in demand. In Appendix I we solve for the value of the marginal employed worker. This is equal to the sum of two terms, where the former denotes the expected present discounted value of a worker and the latter the value of the option to fire him. Hence, a part of the value of a worker stems from the firm's ability to dismiss him if needed at a future date. We will show below that, quite intuitively, the higher is the level of the firing costs, the smaller is the value of the option to fire and the less valuable is the worker.

In order to derive the two thresholds for hiring and firing, we compare the value of the worker to the direct and indirect costs of hiring (firing) the workers. The definitions of the hiring and firing barriers, $Z_{H}$ and $Z_{F}$, are given by the value-matching and smooth-pasting conditions below. According to the value-matching conditions the firm would find it optimal to exercise its option to hire the marginal worker once $Z$ hits a demand threshold defined by the following equation;

$$
K_{1} g Z_{H}-2 K_{2} b g^{2} N-K_{3} w+A_{2}\left(g Z_{H}\right)^{\beta_{2}}=T+A_{1}\left(g Z_{H}\right)^{\beta_{1}},
$$

where $T$ denotes the direct costs of hiring, and $K_{1}, K_{2}$ and $K_{3}$ are as defined in the appendix. The marginal benefit of hiring a worker - shown on the left-hand side of the equation - is the sum of the present discounted value of his productivity net of wages and the value of the option to fire him. The firm's ability to fire raises the benefit from employing a worker. The marginal cost of hiring - on the right-hand side of the equation - is then the sum of the direct hiring costs and the sacrificed option to hire him at a later date. By hiring a

costs have longer unemployment durations. However, the effect of the probability of downturns and productivity growth on this result is unclear.

${ }^{7}$ Bertola (1999) describes some of the work done on the interaction between employment protection and real-wage rigidity. 
worker today, the opportunity to do so in the future, when conditions may be even more favourable, is sacrificed.

The firing decision is described by this equation

$$
-\left[K_{1} g Z_{F}-2 K_{2} b g^{2} N-K_{3} w\right]+A_{1}\left(g Z_{F}\right)^{\beta_{1}}=F+A_{2}\left(g Z_{F}\right)^{\beta_{2}},
$$

where $F$ denotes the firing costs. By firing a worker, the opportunity to do so in the future when demand conditions may be even more adverse - is sacrificed, and the opportunity to hire him again is gained. The left-hand side of the equation shows the marginal benefit of firing, which is equal to the sume of the inverse of the expected discounted marginal profits (negative) and the hiring option. The marginal cost - shown on the right-hand side is then equal to the sum of the direct firing costs $F$ and the sacrificed firing option.

The value of the two options depends on expectations about changes in demand. The option to hire is valuable if firms expect demand to increase in the future, while the option to fire is the more important if they expect it to fall. Importantly, the value of the firing option is decreasing in the level of the firing costs and the level of the hiring option is decreasing in the level of the hiring costs.

We solve the two equations, (8) and (9), numerically for the values of $Z_{\mathrm{H}}$ and $Z_{\mathrm{F}}$, while two more equations are needed to solve for $A_{1}$ and $A_{2}$. These are the so-called smoothpasting conditions ensure that hiring (firing) is not optimal either before nor after the hiring(firing) theshold is reached.

$$
\begin{gathered}
K_{1} g+A_{2} \beta_{2} Z_{H}^{\beta_{2}-1} g^{\beta_{2}}=A_{1} \beta_{1} Z_{H}^{\beta_{1}-1} g^{\beta_{1}}, \\
-K_{1} g+A_{1} \beta_{1} Z_{H}^{\beta_{1}-1} g^{\beta_{1}}=A_{2} \beta_{2} Z_{H}^{\beta_{2}-1} g^{\beta_{2}} .
\end{gathered}
$$

Equations (8), (9), (10) and (11) form a non-linear system of equations with four unknown parameters, $Z_{H}, Z_{F}, A_{1}$ and $A_{2}$, and can be solved for numerically once the solutions for $\beta_{1}$ and $\beta_{2}$ are found from (A4). We refer to the relationships between the level of firing costs, on the one hand, and the level of demand at which firms start hiring and firing workers, on the other hand, as respectively the hiring- and the firing thresholds.

\section{Macroeconomic factors}

We now use the model to examine how the employment effects of firing costs depend on expected productivity growth and the probability of adverse demand shocks. According to 
our stylized account, most OECD countries experienced substantially higher productivity growth and a substantially lower probability of adverse demand shocks in the 1950s and 1960s than subsequently in the 1970s and 1980s. We examine whether these secular changes could have affected the role firing costs play in promoting or hampering production and employment activity.

Accordingly, let us consider three scenarios. First, we let productivity grow at $2.5 \%$ per annum while the (net) probability of adverse demand shocks is kept at zero. We take this benchmark scenario as the analogue to the economic situation in many OECD countries during the 1950s and 1960s. Second, we consider the case of a $20 \%$ probability of a large downturn and a $5 \%$ probability of a positive jump in demand $\left(Z_{H}^{\prime}\right.$ and $\left.Z_{F}{ }_{F}\right)$ - where the size of the jumps is equal - while productivity growth remains at $2.5 \%$. We call this the downturn scenario. Finally, we let productivity growth slow down to $1 \%$ while ignoring the possibility of demand shocks. This is the low-productivity-growth scenario. The last two scenarios - corresponding to low growth and a possibility of adverse demand shocks - are intended to throw light on the effect of changes in the macroeconomic environment between the 1960s, on the one hand, and the 1970s and 1980s, on the other hand.

We want to measure the effectiveness of raising firing costs under the three alternative scenarios. We start by defining what we mean by effectivenss:

Definition: The effectiveness of firing restrictions is given by the slope of the hiring- and the firing thresholds, which show the effect of a given change in firing costs on the level of demand at which firms start hiring (firing) workers. In particular, raising firing costs is effective when this reduces the rate of job destruction without significantly affecting the rate of job creation.

Figure 1 illustrates how the employment effects of firing costs depend on anticipations of cyclical downturns. In particular, it shows the effects of firing costs on the hiring- and the firing thresholds under the benchmark and downturn scenarios. Note that the thresholds have been normalised to start at the same value. 


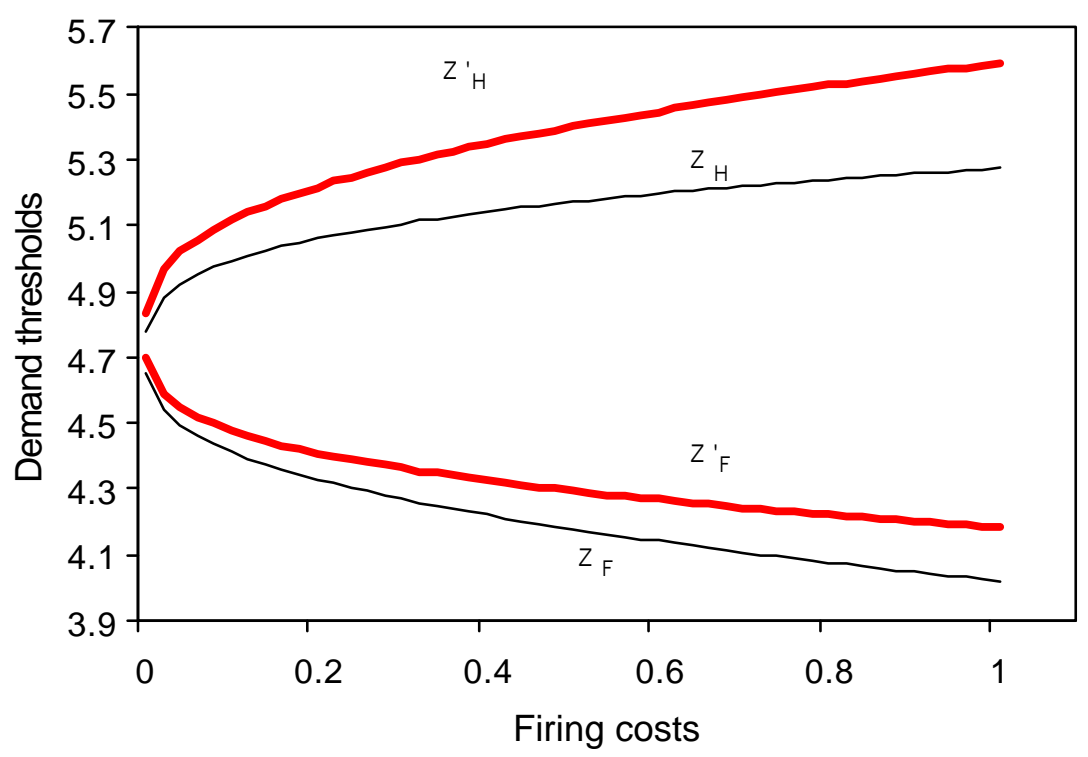

Figure 1. The downturn scenario. The effect of firing costs on the hiring- and firing thresholds with parameters corresponding to the benchmark scenario $\left(\lambda_{1}=\lambda_{2}=0, \sigma_{\mathrm{Z}}\right.$ $=0.12)$ and the downturn scenario $\left(\lambda_{1}=0.20, \lambda_{2}=0.05, \phi_{1}=\phi_{2}=0.3, \sigma_{\mathrm{Z}}=0.01\right)$. Other parameters: $\eta_{\mathrm{g}}=0.025 . \eta_{\mathrm{Z}}=0.0, \delta=0.01, \rho=0.05, T=0.001$, the initial value for $N=$ 1 , the initial value for $g=1$, initial $w=1$. The latter thresholds are distinguished by a prime.

The figure reveals that the expectation of an adverse demand shock makes the hiring threshold steeper and the firing threshold flatter. In the benchmark scenario, the hiring threshold is comparatively flat in relation to the firing threshold, whereas in the downturn scenario the firing threshold is comparatively flat. In this way the negative effects of firing costs on hiring are increased in the downturn scenario while any beneficial effect on firing is reduced. We conclude that firing costs lose some of their effectiveness under this scenario.

The intuition behind the results is straightforward. When the firm expects bad things to happen, the value of the option to fire is high. But an increase in the level of firing costs reduces this value, hence reduces the value of an employed worker to the firm. By reducing the value of workers when their jobs are most under a threat, hiring and firing is affected adversely. This offsets some of the direct effects of firing costs. It follows that the imposition of firing costs is not likely to help since it will primarily reduce incentives to hire workers. ${ }^{8}$

\footnotetext{
${ }^{8}$ Empirical results by Davis et al. (1996) give empirical support for these results; rates of job destruction were not systematically lower in countries with higher employment protection, they were no higher in Europe than in the United States. Blanchard and Portugal (1998) compare job flows in Portugal - high employment protection - and the United States - low employment protection. They find that the annual
} 
Figure 2 describes how the employment effect of firing costs depend on the rate of productivity growth. In particular, it shows the benchmark and the low-productivitygrowth scenarios. Importantly, we let wages grow at the same rate as productivity in both scenarios. The fall in the expected rate of growth of labour productivity also makes the firing threshold flatter but now without visibly affecting the slope of the hiring threshold. Again, firing costs become less effective at deterring layoffs.

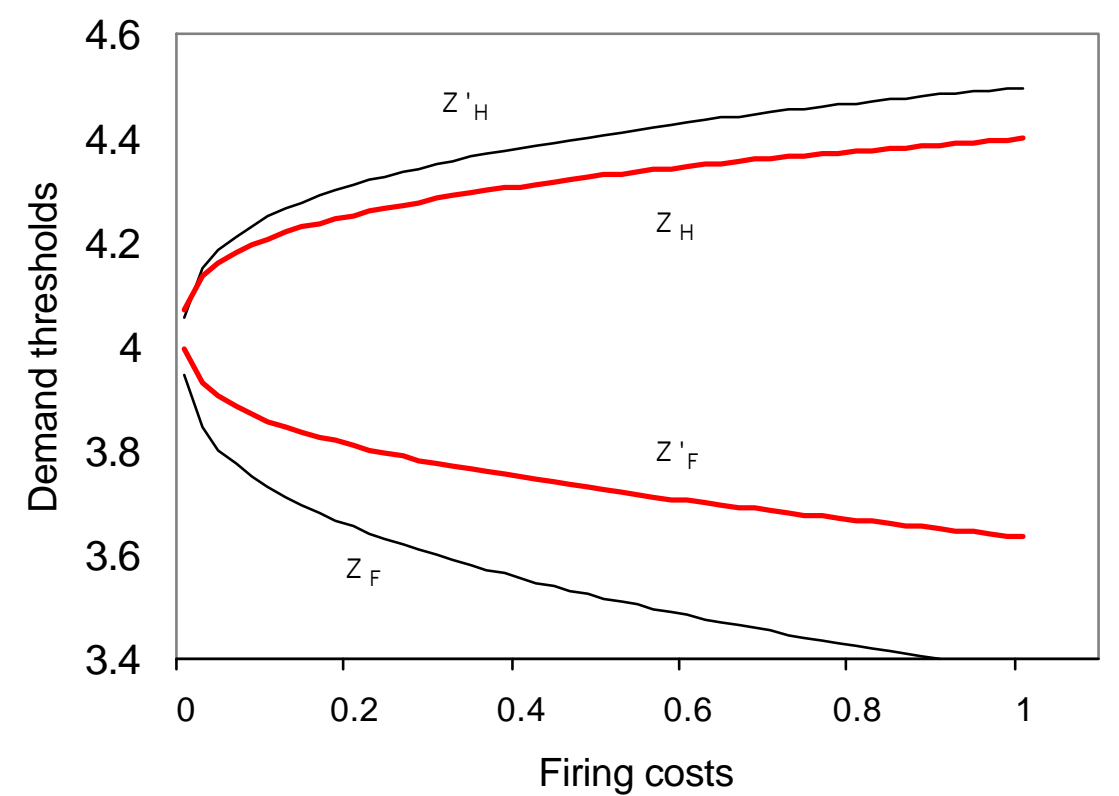

Figure 2. The low-productivity-growth scenario. The effect of firing costs on the hiring- and firing thresholds with parameters corresponding to the benchmark scenario $\left(\eta_{\mathrm{g}}=0.025\right)$ and the low-productivity-growth scenario $\left(\eta_{\mathrm{g}}=0.01\right)$. Other parameters: $\lambda_{1}=\lambda_{2}=0, \sigma_{\mathrm{Z}}=0.12, \eta_{\mathrm{Z}}=0.0, \delta=0.01, \rho=0.05, T=0.001, b=0.5$. Initial value for $N=1$ and initial value for $g=1, \mathrm{w}=1$. The latter thresholds are distinguished by a prime.

The question arises whether wage growth can realistically be expected to respond immediately to changes in the rate of labour productivity growth. One popular macroeconomics textbook discusses the implications of a slow realisation of changes in productivity (Blanchard (1999)). Measures of productivity growth tend to be very volatile and for that reason it may take time for workers and firms to realise that the trend rate of productivity growth has changed. A related argument can be found in a recent paper by Ball 
and Moffit (2001). Here the rate of technical progress shapes wage aspirations or wage norms. Workers gradually get used to and as a result learn to expect a given rate of wage growth. As a result, wage growth only adjusts to changes in the rate of productivity growth with a long lag since wage growth depends on the evolution of social norms which give the "fair" rate of wage increases. If these norms only reflect productivity growth with a lag then so do also wages. ${ }^{9}$

Relaxing the assumption that wage growth adjusts to changes in the rate of growth of productivity does not affect our results in Figure 2; the slopes of the two sets of thresholds in the low-productivity-growth scenario would remain the same. However, if wages continue to grow at rate $2.5 \%$ both the hiring and the firing thresholds will be positioned at a higher level than when they grow at rate $1 \%$. Therefore, firms are less keen to hire and more willing to fire when wages continue to grow at rate $2.5 \%$ in spite of a slowdown in the rate of productivity growth. But our measure of the effectivenss of firing cost would be unaffected.

We conclude that firing restrictions may have little adverse effects on employment and possibly even a positive effect when productivity is growing and the possibility of large adverse demand shocks remote. This assumes that these firing restrictions do not lead to large wage increases (and that is a big if!) when workers' bargaining power is enhanced (see Lindbeck and Snower (1988)). Our model can thus possibly explain why many European countries' relatively stringent job security measures appear not to have had significant adverse employment effects in the first two decades following World War II. But lower growth in the seventies and eighties (Maddison (1987)) and the higher probability of adverse shocks may have turned firing restrictions into a significant obstacle to job creation and a likely cause of high unemployment.

\section{Empirics}

The power of labour-market institutions in explaining cross-country differences in average

\footnotetext{
${ }^{9}$ Another rationale for lagged wage responses to productivity is given by Manning (1991). He uses an efficiency wage model to show that higher expected productivity growth - hence higher expected future wage growth - makes workers value their current employment more which then allows firms to pay lower (efficiency) wages. An increase in the rate of productivity will therefore not be followed by an instantaneous rise in the rate of wage growth.
} 
unemployment has been widely documented. ${ }^{10}$ In particular, average unemployment has been found to be positively correlated with measures of the unemployment-benefit replacement ratio, the duration of benefits, and the density and the coverage of labour unions, and inversely correlated with the degree of union- and employer coordination and the level of active labour-market expenditures. In contrast, different authors do not agree on the sign of the empirical reationship between firing costs and unemployment. ${ }^{11}$ Our model implies that the effect of firing costs on hiring and firing - hence job creation, job destruction and employment when we hold real wages fixed - depends on the macroeconomic environment. The model can therefore potentially account for the lack of consensus on the sign of the empirical relationship between employment protection and unemployment.

We first estimate an equation relating average unemployment to the different institutional variables without taking the macroeconomic environment into account. ${ }^{12}$ We estimate the equation using alternatively average unemployment for the 1960s, 1970s, 1980s and 1990s to test for structural stability and report the results in the table below. We use the average value of the institutional variables for 1983-88 in the first three regressions and the average value for 1989-1994 in the last one. ${ }^{13}$

Our results are strongest for the 1980s and the 1970s. For the 1980s, all variables have signficant coefficients with the expected sign and the equation explains close to $80 \%$ of the variation in unemployment. Most importantly, our measure of firing costs has a significant positive coefficient. The results for the 1970s go in the same direction but are slightly weaker, i.e. the coefficient of firing costs is now insignificant at the $5 \%$ level. The results for the 1960s and the 1990s are still weaker. In particular, firing costs do not have a significant

\footnotetext{
${ }^{10}$ See.eg. Nicoletti et al.(2001), Fitoussi et al. (2000), Nickell and Layard (1999), Elmeskov et al. (1998), Nickell (1998), Scarpetta (1996), Jackman, Layard and Nickell (1991), and Lazear (1990).

${ }^{11}$ We include a survey of the literature on the employment effects of firing costs in Appendix II.

${ }^{12}$ The countries included are: Australia, Austria, Belgium, Canada, Denmark, Finland, France, Germany, Ireland, Italy, Japan, the Netherlands, New Zealand, Norway, Portugal, Spain, Sweden, the U.K., and the U.S.

${ }^{13} \mathrm{We}$ acknowledge that the stringency of firing restrictions has not remained constant over time,. It increased after the oil-price shock in the mid 1970s (e.g. the U.K., the Netherlands and Sweden) and decreased in the early 1980s in many OECD countries (e.g. Germany, the Netherlands, Sweden, the U.K.). However, the timing of changes has been quite uniform across countries and there is perhaps little reason to believe that these changes have affected the relative rankings.
} 
coefficient at all in the 1960s. We can also reject the hypothesis that the coefficient has the same value for all four decades. ${ }^{14}$

The analysis in Section II of this paper suggests where to look for an explanation for the varying significance of the firing-cost variable. In particular, the adverse effect of firing costs should be greatest in those countries having low rates of growth of productivity and facing large negative shocks to demand. We now pool the data for the four decades and use interactive terms to model the coefficient of firing costs. We first report the results of the pooled estimation without any interactive terms in column (5) where firing costs have an insignificant coefficient. We then let the value of the coefficient $c$ depend on the level of trend growth of productivity in a given decade and the magnitude of the largest decline in real GDP during the decade,

$$
c=c_{0}+c_{1} g_{t}+c_{2} S_{t}
$$

where $g$ is the average annual rate of growth of labour productivity ${ }^{15}$ during decade $t$ and $s$ denotes the largest proportional decline in real GDP during the decade. The results are reported in column (6) of the table.

In column (5) all the institutional variables have statistically insignificant - although correctly signed - coefficients. Allowing for the dependance of the effect of firing costs on trend productivity growth and the possibility of adverse shocks then improves the equation considerably as can be seen in column (6). The equation now explains close to half the variation in the sample and the coefficients have gained some significance. Most importantly, the coefficients $c_{1}, c_{2}$ and $c_{3}$ in equation (12) are all correctly signed and significant at the $5 \%$ level. Firing costs are positively correlated with unemployment in the absence of productivity growth and negative shocks. When we allow for shocks, we find that the larger was the biggest decadal fall in real GDP, the higher is the value of the coefficient of firing costs; a given level of firing costs causes unemployment to be higher. In contrast, the coefficient of firing costs is inversely related to trend produtivity growth. The higher is the growth of labour productivity, the smaller is the (positive) effect of firing costs on unemployment.

\footnotetext{
${ }^{14} \mathrm{~F}=18.90$ for $\mathrm{H}_{0}$ : The coefficient is the same for all decades. This gives a rejection at the $5 \%$ confidence level.

${ }^{15}$ Measured as real GDP per employed worker and smoothed by the Hodrick-Prescott filter (smoothing
} 
Average Unemployment and Labour-Market Institutions

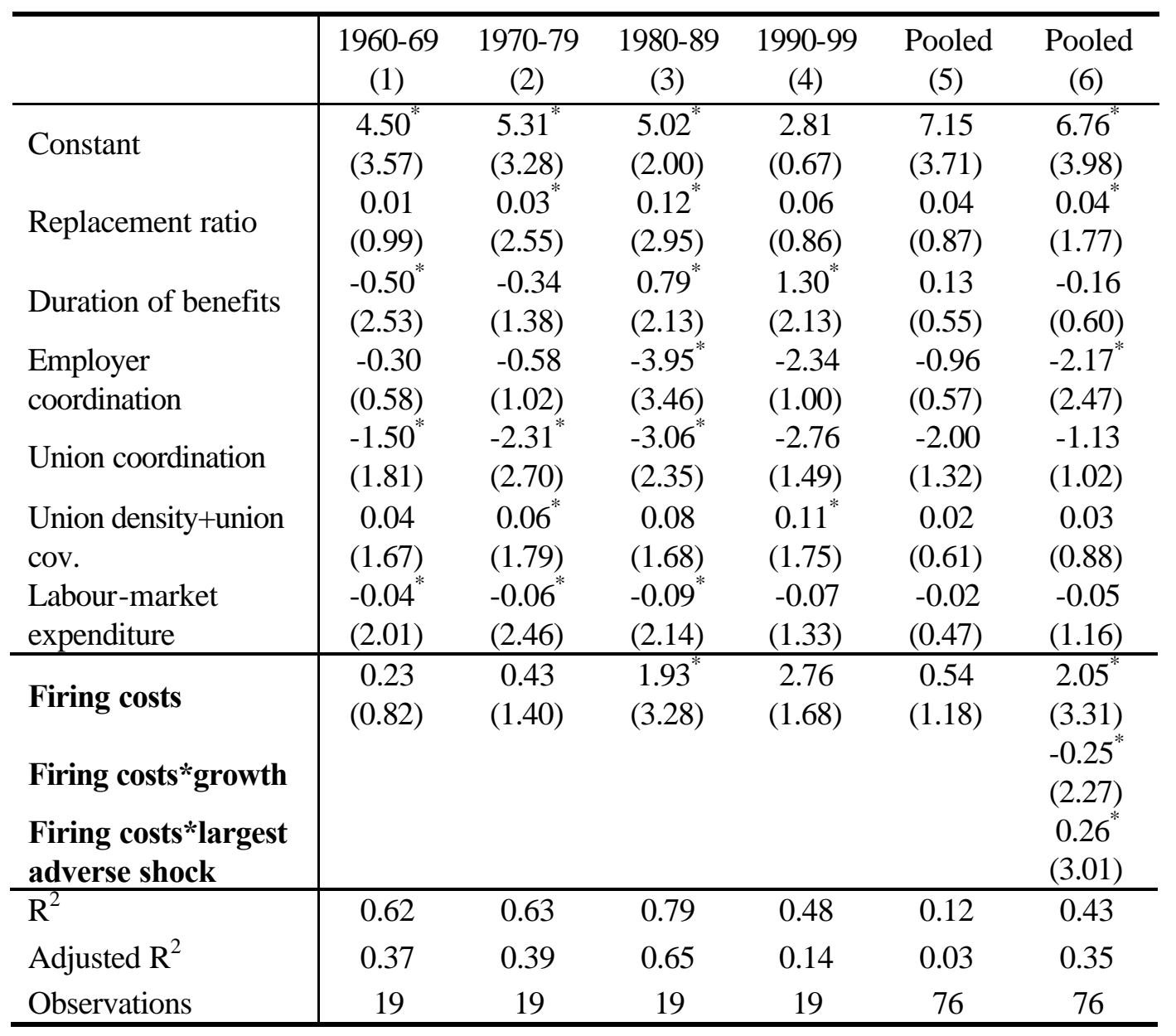

*denotes significance at $5 \%$ level.

Source: Author's calculations using data supplied by Richard Layard and Stephen Nickell. The table shows regressions of the form; $u_{t}=\alpha+\beta Y+\varepsilon$, where $u_{\mathrm{t}}$ is the average unemployment rate in a given decade and $Y$ is the set of explanatory variables. The institutional measures ${ }^{16}$ are

parameter equal to 100$)$.

${ }^{16}$ The replacement ratio is defined as the ratio of unemployment benefits to wages; the duration of benefits is the maximum number of months that workers can collect unemployment benefits; union density measures the proportion of the labour force belonging to labour unions; union coverage shows 
averages for the nineteen countries for the period 1983-1988 - first three columns - and 1989-94fourth column. Growth measures average trend growth of labour productivity over a decade measured as real GDP per employed worker - and the largest adverse shock to GDP is taken to be the largest rate of decline in aggregate real GDP between any two years during the decade.

In order to illustrate our results further we plot the coefficient of firing costs as a function of the average rate of growth over the decade and the size of the largest recession in Figure 3.

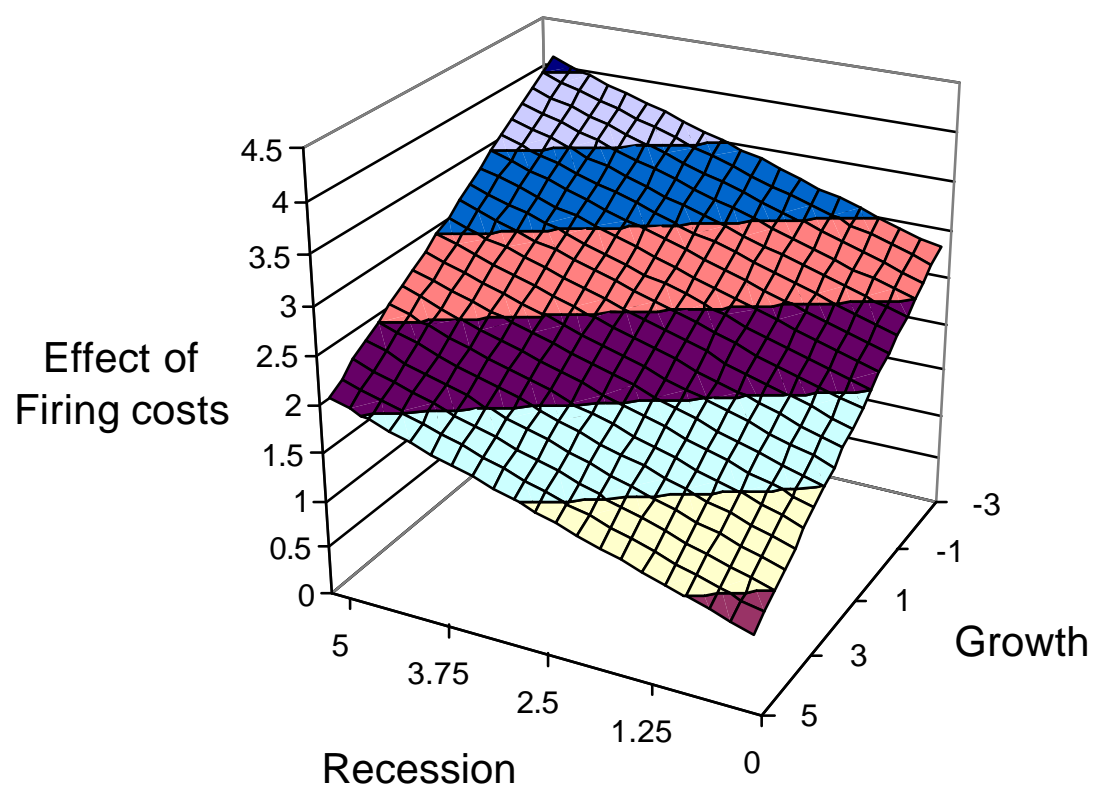

Figure 3. The effect of firing costs on unemployment. The coefficient of firing costs shown as a function of the average rate of growth of productivity and the magnitude of the largest recession - measured as the largest proportional fall in real GDP - over a decade.

The question remains if changes in firing costs, productivity growth and the size of anticipated shocks can account for differences in the change in average unemployment over time across the nineteen countries. We have measures of firing costs for both the period 1983-1988 and 1989-1994. We can use these measures, as well as data on productivity

the proportion of the labour force covered by union wage settlements; union- and employer coordination are indices for coordination among different unions and employers during wage bargaining; labour market expenditures is expenditure on active labour market programmes per unemployed person as a percentage of output per person; and, finally; firing costs are measured by the number of months salary that goes into mandatory redundancy payments. Source: Nickell and Layard (1999). 
growth and the size of the shocks in the two decades, to predict changes in average unemployment between the 1980s and the 1990s. ${ }^{17}$ The results are shown in Figure 4.
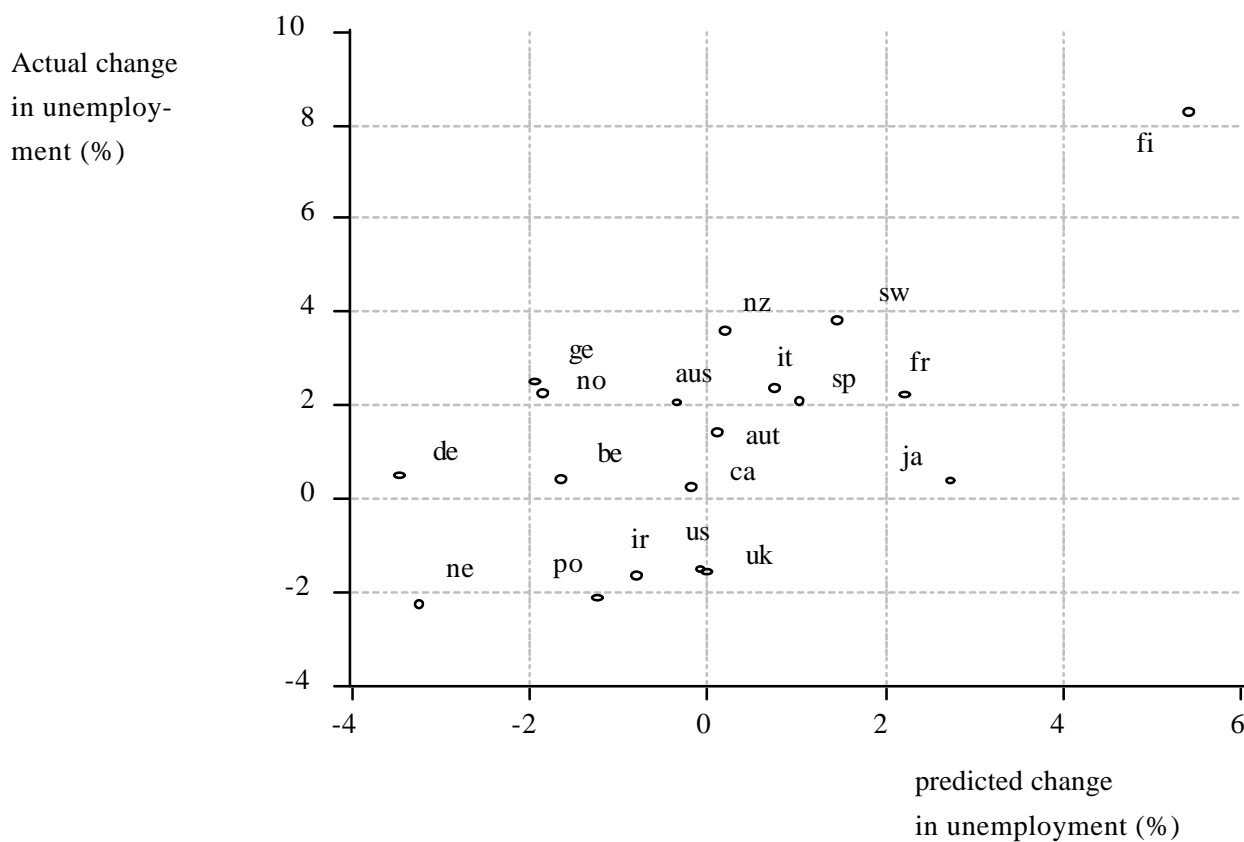

Figure 4. Predicted and actual change in average unemployment 1980-89 to 1990-99. The prediction is based on the coefficient of firing costs reported in the table above and shown in Figure 3.

The equation does a good job at explaining the rise in unemployment as can be seen from the high correlation between the predicted and the actual rise in unemployment $(0.62)$.

\section{Conclusions}

Macroeconomic outcomes reflect the interplay of institutions, macroeconomic shocks and policy responses. It follows that one should not study macroeconomic policy without paying attention to the institutional environment: A given set of policies may be appropriate in one country and not in another due to institutional differences. Similarly, institutional reforms such as those recommended by the OECD - may be sensible in a given macroeconomic

\footnotetext{
${ }^{17}$ The formula is the following where $g$ denotes productivity growth and $s$ the size of the largest negative shock,
} 
environment and not in another. We conclude that a sensible formulation of structural reforms requires understanding of the interplay between institutions, the nature of cyclical shocks and the level of labour productivity growth. We hope this paper contributes to this understanding.

$$
\begin{aligned}
u_{90 s}-u_{80 s}=2.05 *\left(e p l_{90 s}-e p l_{80 s}\right) & -0.25\left[\left(g_{90 s}-g_{80 s}\right) e p l_{80 s}+g_{80 s}\left(e p l_{90 s}-e p l_{80 s}\right)\right] \\
& +0.26\left[\left(s_{90 s}-s_{80 s}\right) e p l_{80 s}+s_{80 s}\left(e p l_{90 s}-e p l_{80 s}\right)\right]
\end{aligned}
$$




\section{Appendix I}

\section{Derivation of the Hiring- and the Firing Thresholds}

To find the value of the marginal employed worker, we take the derivative of (7) with respect to $N$

$$
\begin{aligned}
& (\rho+\delta) v=g Z-2 b g^{2} N-w-\delta N v_{N}+\eta_{g} g v_{g} \\
& +\eta_{Z} Z v_{Z}+\frac{1}{2} \sigma_{Z}^{2} Z^{2} v_{Z Z}-\lambda_{1}\left\{v-v\left[\left(1-\phi_{1}\right) Z\right]\right\}+\lambda_{2}\left\{v\left[\left(1+\phi_{2}\right) Z\right]-v\right\} .
\end{aligned}
$$

where $v(Z, g, N)$ is the value of employing the marginal worker. The solution for $v(Z, g, N)$ consists of the particular integral and the complementary function. The particular integral, which is the expected present value of the marginal employed worker, is ${ }^{18}$

$$
v^{P}(Z, g, N)=K_{1} g Z-2 K_{2} b g^{2} N-K_{3} w,
$$

where

$$
\begin{aligned}
& K_{1}=\left(\rho+\delta+\lambda_{1} \phi_{1}-\lambda_{2} \phi_{2}-\eta_{g}-\eta_{z}\right)^{-1}, \\
& K_{2}=\left(\rho+2 \delta-2 \eta_{g}\right)^{-1}, \\
& K_{3}=\left(\rho+\delta-\eta_{g}\right)^{-1}
\end{aligned}
$$

are the three discount factors.

The firm's option value of hiring in the future and its option value of firing once the worker is employed are measured by the complementary function:

$$
\begin{aligned}
(\rho+\delta) v=-\delta N v_{N} & +\eta_{g} g v_{g}+\eta_{Z} Z v_{Z}+\frac{1}{2} \sigma_{Z}^{2} Z^{2} v_{Z Z} \\
- & \lambda_{1}\left\{v-v\left[\left(1-\phi_{1}\right) Z\right]\right\}+\lambda_{2}\left\{v\left[\left(1+\phi_{2}\right) Z\right]-v\right\} .
\end{aligned}
$$

The general solution to equation (A4) has the same component as the complementary ones. That is, the general solution has the following functional form

$$
v=A(g Z)^{\beta} \text {. }
$$

This gives the following relationships

$$
\begin{gathered}
\eta_{g} g v_{g}=\eta_{g} \beta v \\
\delta N v_{N}=0 \\
\eta_{Z} Z v_{Z}=\eta_{Z} \beta v,
\end{gathered}
$$

\footnotetext{
${ }^{18}$ In particular, the particular integral may be expressed as

$$
v(Z, g, N)=E \int_{0}^{\infty}\left[g_{t} Z_{t}-2 b g_{t}^{2} N_{t}-w_{t}\right] e^{-(\rho+\delta) t} d t
$$
}

which reduces to equation (9) in the absence of hiring and firing. 


$$
\begin{gathered}
\frac{1}{2} \sigma_{Z}^{2} Z^{2} v_{Z Z}=\frac{1}{2} \sigma_{Z}^{2} \beta(\beta-1) v, \\
v\left[\left(1-\phi_{1}\right) Z\right]=\left(1-\phi_{1}\right)^{\beta} v . \\
v\left[\left(1+\phi_{2}\right) Z\right]=\left(1+\phi_{2}\right)^{\beta} v .
\end{gathered}
$$

Substituting (A6), (A7), (A8), (A9) (A10) and (A11) into (A4) gives

$$
v\left[\frac{1}{2} \sigma_{Z}^{2} \beta(\beta-1)+\eta_{Z} \beta+\eta_{g} \beta-\lambda_{1}\left[1-\left(1-\phi_{1}\right)^{\beta}\right]+\lambda_{2}\left[\left(1+\phi_{2}\right)^{\beta}-1\right]-(\rho+\delta)\right]=0 .
$$

Equation (A12) must hold for any value of $v$, so that bracketed terms must equal zero:

$$
\frac{1}{2} \sigma_{Z}^{2} \beta(\beta-1)+\eta_{Z} \beta+\eta_{g} \beta-\lambda_{1}\left[1-\left(1-\phi_{1}\right)^{\beta}\right]+\lambda_{2}\left[\left(1+\phi_{2}\right)^{\beta}-1\right]-(\rho+\delta) .
$$

Thus, (A5) becomes

$$
v=A_{1}(g Z)^{\beta_{1}}+A_{2}(g Z)^{\beta_{2}} .
$$

where $\beta_{1}$ and $\beta_{2}$ are the positive and negative roots of (A4).

The general solutions are equal to the value of the options to fire or hire the marginal worker. When $Z$ goes to infinity, the value of the option to fire has to go to zero. Hence $A_{1}$ is equal to zero for the value of option to fire. ${ }^{19}$ Similarly, when $Z$ approaches zero, the value of the option to hire has to go to zero. Hence we set $A_{2}=0$ for the value of option to fire.

The general solutions for the hiring and firing options have the following forms respectively,

$$
\begin{gathered}
v_{H}^{G}(N, Z, g)=A_{1}(g Z)^{\beta_{1}}, \\
v_{F}^{G}(N, Z, g)=A_{2}(g Z)^{\beta_{2}} .
\end{gathered}
$$

where $\beta_{1}$ and $\beta_{2}$ are the positive and negative roots of the following characteristic equation:

$$
\frac{1}{2} \sigma_{Z}^{2} \beta(\beta-1)+\eta_{Z} \beta+\eta_{g} \beta-\lambda_{1}\left[1-\left(1-\phi_{1}\right)^{\beta}\right]+\lambda_{2}\left[\left(1+\phi_{2}\right)^{\beta}-1\right]-(\rho+\delta)
$$

To satisfy the boundary conditions that $v_{H}^{G}(0, g, N)=0$ and $v_{F}^{G}(\infty, g, N)=0$, we use the positive solution for $v_{H}^{G}$ and the negative solution for $v_{F}^{G}$.

\footnotetext{
${ }^{19}$ Note that $\beta_{1}$ is positive and $\beta_{2}$ is negative.
} 


\section{Appendix II \\ Literature survey on the effects of employment protection on unemployment}

There is a growing literature - theoretical as well as empirical - on the effects of employment protection legislation on both the variance of unemployment as well as the average level of employment and unempoloyment.

Bentolila and Bertola (1990), Bertola (1992) and Layard and Nickell (1998) show that firing costs are likely to reduce unemployment turnover and make the unemployment pool more stagnant. Blanchard and Portugal (1998) concur in their comparison of the Portuguese and the US labour markets. ${ }^{20}$ However, they claim that the implications of lower turnover for the average unemployment rate are unclear. In an earlier paper, Gavin (1986) finds that the effect depends on the state of demand: Employment is raised when demand is low, but decreased when demand is high. The net effect on average employment is indeterminate. Interestingly, Bentolila and Bertola (1990) give a more definite answer. They show that due to time discounting, the effect of firing costs on the firing decision should dominate their effect on the hiring decision - firms discount the firing costs when making the hiring decision. Holding wages fixed and exogenous, they show that the average level of labour demand is likely to rise when the firing restrictions are made more stringent.

While the effect of EPL on labour turnover appears empirically to be well documented, there is less agreement when it comes to the average level of employment and unemployment. Lazear (1990) studies data on employment protection, employment, unemployment and labour-force participation in 22 countries over a period of 29 years. $^{21}$ He finds a significantly negative effect of EPL on the employment-population ratio and the labour-force participation rate. Scarpetta (1996) finds an inverse relationship between firing costs and the employment-to-population ratio using a panel of OECD countries. However, Nickell and Layard (1998) claim that this result may be largely caused by low participation rates in southern Europe which also happen to have stict EPL. There is also limited

\footnotetext{
${ }^{20}$ However, studies of employment turnover (Bertola and Rogerson (1997) and Boeri (1999) find similar job creation and job destruction rates across countries with different EPL regimes. This may suggest more frequent job-to-job shifts in the rigid labour markets.
} 
consensus on the effect of EPL on unemployment. While Layard and Nickell (1998) find no such effect, Lazear (1990) found a significant positive effect, as did Elmeskov, Martin and Scarpetta (1998) using the OECD summary index of formal employment protection. However, Addison and Grosso (1996) find no significant evidence when using data similar to those used by Lazear. Moreover, in an earlier paper, Blanchard and Jimeno (1995) point out that the degree of enforcement of employment protection differs significantly between Spain and Portugal despite similar summary indicators of the strictness of the legistlation. DiTella and MacCulloch (1998) take this criticism seriously and use data based on surveys of business people over the 1980s and find a positive relationship between EPL regulation and unemployment. Finally, in a recent contribution, Blanchard and Landier (2000) show that limited liberalisation - which makes fixed-term contracts easier to impliment - may paradoxically raise average unemployment by raising turnover and unemployment among temporary workers.

\section{References}

Addison, John T. and Jean-Luc Grosso (1996), “Job Protection and Employment: Revised Estimates," Industrial Relations, 35, p. 585-603.

Ball, Laurence and Robert Moffit (2001), "Productivity Shifts and the Phillips Curve," unpublished manuscript, Bank of England.

Bentolila, Samuel and Giuseppe Bertola (1990), "Firing Costs and Labor Demand: How Bad is Eurosclerosis?", Review of Economic Studies, 57, p. 381-402.

Bertola, Guiseppe (1990), "Job Security, Employment and Wages", European Econoimc Review, 34, p. 851-886.

Bertola, Guiseppe (1992), "Labor Turnover Costs and Average Labor Demand," Journal of Labor Economics, 4, p. 389-411.

Bertola, Guiseppe and Richard Rogerson (1997), "Institutions and Labour Reallocation," European Economic Review, 41, p. 147-1171.

Bertola, Guiseppe (1999), "Microeconomic Perspectives on Aggregate Labour Markets", in Ashenfelter and Card (eds.), Handbook of Labour Economics, North Holland, Amsterdam.

Blanchard, Oliver J. and Juan F. Jimeno (1995), "Structural Unemployment: Spain Versus Portugal," American Economic Review, Papers and Proceedings, 85, p. 212-218.

\footnotetext{
${ }^{21}$ He measures EPL by the number of months of salary given to workers as severance pay upon dismissal after ten years of service and the number of months notice required before termination to workers with ten years of service.
} 
Blanchard, Olivier J. and P. Portugal (1998), "What Hides Behind an Unemployment Rate: Comparing Portuguese and US Unemployment," National Bureau of Economic Research, working paper no. 6636. Forthcoming in the American Economic Review.

Blanchard, Olivier J. and J. Wolfers (2000), "The role of shocks and institutions in the rise of European unemployment: the aggregate evidence," Economic Journal, 110.

Blanchard, Olivier and Augustin Landier (2000), "The Perverse Effects of Partial Labor Market reform: Fixed Duration Contracts in France," manuscript, MIT.

Blanchard, Olivier (1999), Macroeconomics, Second Edition, Prentice Hall; Upper Saddle River, NJ..

Boeri, Tito (1999), "Enforcement of Employment Security Regulations, On-the-Job Search and Unemployment Duration," European Economic Review, 43, p. 65-89.

Booth, Alison and Gylfi Zoega (1994), "Quitting Externalities, Employment Cyclicality and Firing Costs", CEPR Discussion Paper No. 1101.

Carruth, A.A., M.A. Hooker and Andrew J. Oswald (1998), "Unemployment equilibria and input prices: Theory and evidence from the United States", manuscript, Warwick University.

Davis, Steven, Haltiwanger, J. and S. Schuh (1996), Job Creation and Job Destruction, MIT Press; Cambridge Mass.

DiTella, R. and R. MacCulloch (1998), "The Consequences of Labor Market Flexibility: Panel Evidence Based on Survey Data," mimeo.

Diaz, M. Pilar , and Dennis J. Snower(1996), "Employment, Macroeconomic Fluctuations and Job Security," Birkbeck Discussion paper \# 11/96.

Dixit, Avinash K. (1993), The Art of Smooth Pasting, Vol. 55 in Fundamentals of Pure and Applied Economics, eds. Jacques Lesourne and Hugo Sonnenschein, Chur, Switzerland, Harwood Academic Publishers.

Dixit, Avinash K. and Robert S. Pindyck (1994), Investment under Uncertainty, Princeton University Press; Princeton, New Jersey.

Elmeskov, Jorgen, John Martin, and Stefano Scarpetta (1998), "Key Lessons for Labour Market Reforms: Evidence from OECD Countries' Experiences, ” Swedish Economic Policy Review 5 (2), p. 205-52.

Fitoussi, Jean-Paul, David Jestaz, Edmund S. Phelps and Gylfi Zoega (2000), "Roots of the Recent Recoveries: Labor Reforms or Private Sector Forces?", Brookings Papers on Economic Activity, p. 237-291.

Hoon, H. T. and Edmund S. Phelps (1997), "Growth, wealth and the natural rate: is the European job crisis a growth crisis?", European Economic Review, 41, p. 549-57.

Lazear, Edward P. (1990), "Job Security Provisions and Employment", Quarterly Journal of Economics, 105, p. 699-726.

Giersch, H. (1985), "Eurosclerosis”, Kiel Discussion Papers no. 112, Kiel.

Layard, Richard, Stephen Nickell and Richard Jackman (1991), Unemployment: Macroeconomic Performance and the Labour Market, Oxford University Press. Lindbeck, Assar and Dennis J. Snower(1988), The Insider-Outsider Theory of Employment and Unemployment, Cambridge, MA, The MIT Press.

Ljungqvist, Lars and Thomas J. Sargent (1998), “The European Unemployment Dilemna," Journal of Political Economy, 106, p. 514-550. 
Maddison, Angus (1987), "Growth and Slowdown in Advanced Capitalist Economies: Techniques of Quantitative Assessment," Journal of Economic Literature, XXV, p.649699.

Manning, Alan (1991), "Productivity Growth, Wage Setting and the Equilibrium Rate of Unemployment." Paper presented at the NBER Conference on Unemployment and Wage Determination, Cambridge, MA.

McDonald, Robert, and Daniel R. Siegel, (1987), "Time to Build, Option Value, and Investment Decisions," Quarterly Journal of Economics, 101, p. 707-728.

Malliaris, A. G. and William A. Brock (1982), Stochastic Methods in Economics and Finance, New York: North-Holland.

Nickell, Stephen (1998), “Unemployment: Questions and some Answers, ” The Economic Journal, 108, p. 802-16.

Nickell, Stephen and Richard Layard (1999), "Labor Market Institutions and Economics Performance." In The Handbook of Labor Economics, edited by Orley Ashenfelter and David Card. North-Holland; Amsterdam.

Nicoletti, Giuseppe, Robert C.G. Haffner, Stephen Nickell, Stefano Scarpetta, and Gylfi Zoega (2001), "European Integration, Liberalization, and Labor-Market

Performance," in Guiseppe Bertola, Tito Boeri and Giuseppe Nicoletti (eds.), Welfare and Employment in a United Europe. The MIT Press; Cambridge Mass.

OECD (2000), Policies Towards Full Employment, Paris: OECD.

Phelps, Edmund S. (1994). Structural Slumps: The Modern Equilibrium Theory of Unemployment, Interest and Assets. Cambridge: Harvard University Press.

Phelps, Edmund S. and Gylfi Zoega (2001), "Structural Booms: Productivity Expectations and Asset Valuations," forthcoming in Economic Policy.

Pissarides, C. A. (1990), Equilibrium Unemployment Theory. Oxford: Blackwell. Scarpetta, Stefano (1996), "Assessing the Role of Labour Market Policies and Institutional Settings on Unemployment: A Cross Country Study," OECD Economic Studies, 26, p. 43-98. 


\section{IZA Discussion Papers}

\begin{tabular}{|c|c|c|c|c|}
\hline No. & Author(s) & Title & Area & Date \\
\hline 522 & $\begin{array}{l}\text { S.-Å. Dahl } \\
\varnothing . \text { A. Nilsen } \\
\text { K. Vaage }\end{array}$ & $\begin{array}{l}\text { Gender Differences in Early Retirement } \\
\text { Behaviour }\end{array}$ & 3 & $06 / 02$ \\
\hline 523 & $\begin{array}{l}\text { J. Falkinger } \\
\text { V. Grossmann }\end{array}$ & $\begin{array}{l}\text { Workplaces in the Primary Economy and Wage } \\
\text { Pressure in the Secondary Labor Market }\end{array}$ & 3 & $07 / 02$ \\
\hline 524 & $\begin{array}{l}\text { J. J. Dolado } \\
\text { F. Felgueroso } \\
\text { J. F. Jimeno }\end{array}$ & $\begin{array}{l}\text { Recent Trends in Occupational Segregation by } \\
\text { Gender: A Look Across the Atlantic }\end{array}$ & 2 & $07 / 02$ \\
\hline 525 & $\begin{array}{l}\text { J. J. Heckman } \\
\text { C. Heinrich } \\
\text { J. Smith }\end{array}$ & The Performance of Performance Standards & 6 & $07 / 02$ \\
\hline 526 & $\begin{array}{l}\text { E. Leuven } \\
\text { H. Oosterbeek }\end{array}$ & $\begin{array}{l}\text { A New Approach to Estimate the Wage Returns } \\
\text { to Work-Related Training }\end{array}$ & 6 & $07 / 02$ \\
\hline 527 & J. C. van Ours & The Locking-in Effect of Subsidized Jobs & 4 & $07 / 02$ \\
\hline 528 & $\begin{array}{l}\text { P. Manzini } \\
\text { M. Mariotti }\end{array}$ & $\begin{array}{l}\text { Arbitration and Mediation: An Economic } \\
\text { Perspective }\end{array}$ & 3 & $07 / 02$ \\
\hline 529 & $\begin{array}{l}\text { J. M. Orszag } \\
\text { D. Snower }\end{array}$ & Incapacity Benefits and Employment Policy & 3 & $07 / 02$ \\
\hline 530 & $\begin{array}{l}\text { M. Karanassou } \\
\text { D. Snower }\end{array}$ & Unemployment Invariance & 3 & $07 / 02$ \\
\hline 531 & $\begin{array}{l}\text { M. Karanassou } \\
\text { H. Sala } \\
\text { D. Snower }\end{array}$ & $\begin{array}{l}\text { Unemployment in the European Union: A } \\
\text { Dynamic Reappraisal }\end{array}$ & 3 & $07 / 02$ \\
\hline 532 & $\begin{array}{l}\text { J. M. Orszag } \\
\text { D. Snower }\end{array}$ & $\begin{array}{l}\text { From Unemployment Benefits to Unemployment } \\
\text { Accounts }\end{array}$ & 3 & $07 / 02$ \\
\hline 533 & $\begin{array}{l}\text { S. Fölster } \\
\text { R. Gidehag } \\
\text { M. Orszag } \\
\text { D. Snower }\end{array}$ & Assessing Welfare Accounts & 3 & $07 / 02$ \\
\hline 534 & $\begin{array}{l}\text { A. Lindbeck } \\
\text { D. Snower }\end{array}$ & The Insider-Outsider Theory: A Survey & 3 & $07 / 02$ \\
\hline 535 & $\begin{array}{l}\text { P. Manzini } \\
\text { D. Snower }\end{array}$ & $\begin{array}{l}\text { Wage Determination and the Sources of } \\
\text { Bargaining Power }\end{array}$ & 3 & $07 / 02$ \\
\hline 536 & $\begin{array}{l}\text { M. Orszag } \\
\text { D. Snower }\end{array}$ & Pension Taxes versus Early Retirement Rights & 3 & 07/02 \\
\hline 537 & $\begin{array}{l}\text { J. M. Orszag } \\
\text { D. Snower }\end{array}$ & $\begin{array}{l}\text { Unemployment Vouchers versus Low-Wage } \\
\text { Subsidies }\end{array}$ & 3 & 07/02 \\
\hline 538 & $\begin{array}{l}\text { M. Orszag } \\
\text { D. Snower }\end{array}$ & The Pension Transfer Program & 3 & $07 / 02$ \\
\hline 539 & $\begin{array}{l}\text { Y.-F. Chen } \\
\text { D. Snower } \\
\text { G. Zoega }\end{array}$ & $\begin{array}{l}\text { Labour-Market Institutions and Macroeconomic } \\
\text { Shocks }\end{array}$ & 3 & $07 / 02$ \\
\hline
\end{tabular}

